Check for updates

Cite this: RSC Adv., 2018, 8, 22643

\title{
A technology for strongly improving methane production from rice straw: freeze-thaw pretreatment
}

\author{
Yuanfang Deng, ${ }^{\text {ab }}$ Ling Qiu, ${ }^{* a b}$ Yiqing Yao (D) *ab and Mengyao Qin ${ }^{c}$
}

Overcoming the complex three dimensional structure of biomass is a major challenge in enhancing anaerobic digestion (AD) efficacy. Freeze-thaw pretreatment was proposed herein in order to improve methane production from rice straw. The effect was notable: average methane content for group-A ( -4 $\left.{ }^{\circ} \mathrm{C}\right)$ and $-\mathrm{B}\left(-20{ }^{\circ} \mathrm{C}\right)$ were $\mathrm{A} 1\left(-4{ }^{\circ} \mathrm{C}, 12 \mathrm{~h}\right): 40.0 \%, \mathrm{~A} 2\left(-4{ }^{\circ} \mathrm{C}, 24 \mathrm{~h}\right): 40.5 \%, \mathrm{~A} 3\left(-4{ }^{\circ} \mathrm{C}, 48 \mathrm{~h}\right): 42.2 \%$; $\mathrm{B} 1$ $\left(-20{ }^{\circ} \mathrm{C}, 12 \mathrm{~h}\right): 44.2 \%, \mathrm{~B} 2\left(-20{ }^{\circ} \mathrm{C}, 24 \mathrm{~h}\right): 45.7 \%$, B3 $\left(-20{ }^{\circ} \mathrm{C}, 48 \mathrm{~h}\right): 46.0 \%$, the increases were $88.8-$ $99.1 \%$ and $108.8-117.2 \%$, respectively, compared with control (CK) (21.2\%). Total methane production for group-A and -B were A1: $22.8 \mathrm{~mL} \mathrm{~g}^{-1} \mathrm{TS}, \mathrm{A} 2: 24.7 \mathrm{~mL} \mathrm{~g}^{-1} \mathrm{TS}, \mathrm{A} 3: 27.8 \mathrm{~mL} \mathrm{~g}^{-1} \mathrm{TS}$; B1: $29.9 \mathrm{~mL} \mathrm{~g}^{-1} \mathrm{TS}$, B2: $31.3 \mathrm{~mL} \mathrm{~g}^{-1} \mathrm{TS}, \mathrm{B} 3: 32.0 \mathrm{~mL} \mathrm{~g}^{-1} \mathrm{TS}$, compared with $\mathrm{CK}\left(7.6 \mathrm{~mL} \mathrm{~g}^{-1} \mathrm{TS}\right)$, the increases were $200.0-$ $265.8 \%, 293.4-321.1 \%$, respectively. The technical digestion time $\left(T_{80}\right)$ was shortened by 8 days. Therefore, the maximum methane production was obtained under conditions of $-20{ }^{\circ} \mathrm{C}$ and $48 \mathrm{~h}$. This study proposed an efficient pretreatment method that broadens the horizon of improving biomass conversion into bioenergy.

Received 29th April 2018

Accepted 14th June 2018

DOI: 10.1039/c8ra03692f

rsc.li/rsc-advances furfural, phenolic compounds and so on. ${ }^{10,11}$ Because of its low energy consumption and high environmental friendliness, biological method, as a pretreatment method, has become the mainstream research trend. ${ }^{\mathbf{1 2 , 1 3}}$ However, biological pretreatment is a slow enzymolysis process, and the treatment period is generally more than 15 days. Chemical pretreatment is immediate and rapid, but the erosion on pretreatment equipment is usually severe. Exploring a pretreatment method with high-efficiency and environmental friendship, and high applicability on a large scale is an inevitable trend in the development of $\mathrm{AD} . .^{\mathbf{1 4 1 5}}$

In this study, low-temperature freezing and thawing, as a pretreatment method, was proposed, which follows the mechanism of icing swelling of water and its destruction on biomass structure, creating a new pretreatment method for $\mathrm{AD}$ with no pollution, low cost, and cleanness, and is of great significance to the utilization of biowastes. At present, the freeze-thaw treatment is mainly used for sewage sludge, ${ }^{16-21}$ and also used for microalgae with methane recovery ${ }^{22}$ and for some lignocelluosic materials with sugar and ethanol recovery. ${ }^{23}$ However, the related research on lignocellulosic materials for methane production via $\mathrm{AD}$ is rarely studied so far. In order to provide more options for enabling $\mathrm{AD}$ efficiently, it is necessary to investigate the effect of freeze-thaw pretreatment on efficacy of $\mathrm{AD}$ with lignocellulosic materials as substrate.

By mimicking the natural environmental conditions or outdoor low-temperature environment, cold climate was used for freezing and thawing rice straw, the rice straw was subjected to freeze-thaw pretreatment in laboratory. The effects of different freeze-thaw times $(12 \mathrm{~h}, 24 \mathrm{~h}, 48 \mathrm{~h})$ at $-4{ }^{\circ} \mathrm{C}$ and 
$-20{ }^{\circ} \mathrm{C}$ on $\mathrm{AD}$ of rice straw was investigated, including structure changes of rice straw, biogas and methane productions, methane content, total methane production, technical digestion time $\left(T_{80}\right)$ and $\mathrm{pH}$ change.

\section{Materials and methods}

\subsection{Pretreatment}

Rice straw was taken from farmland in Huaiyin District and was naturally air dried and ground with pulverizers installed with screen of 10 mesh $(2.0 \mathrm{~mm})$. The inoculum was obtained from laboratory-adapted $\mathrm{AD}$ sludge with a $\mathrm{pH}$ of 7.1, the characteristics of ground samples and inoculum, including carbon-tonitrogen ratio $(\mathrm{C} / \mathrm{N})$, total solids (TS), cellulose (C), hemicellulose (H), and lignin (L) are shown in Table 1.

The raw material was pretreated in laboratory. The temperature, time, and moisture at the soaking stage was $30^{\circ} \mathrm{C}, 4 \mathrm{~h}$, $15 \mathrm{~mL} \mathrm{~g}^{-1}$, respectively. Deionized water was used as the medium for soaking. Two freezing temperatures $\left(-4{ }^{\circ} \mathrm{C},-20\right.$ ${ }^{\circ} \mathrm{C}$ ) and three freezing times (12 h, $\left.24 \mathrm{~h}, 48 \mathrm{~h}\right)$ at each freezing temperature were carried out (Table 2). Thawed at room temperature $\left(25^{\circ} \mathrm{C}\right)$, samples with the low temperature freezing at $-4{ }^{\circ} \mathrm{C}$ and thawing treatments was set as group $\mathrm{A}$ and group $\mathrm{B}$ was the samples with low temperature freezing at $-20{ }^{\circ} \mathrm{C}$ and thawing treatments. At the same time samples that was not soaked for freezing and thawing treatment was set as control (CK). Each conditions were repeated three time.

\subsection{Set-up of anaerobic digestion}

Hydrostatic AD devices were used in this study, ${ }^{24}$ as shown in Fig. 1, which is mainly composed of a fermenter, a gas collection bottle, a measuring cylinder, and a constant temperature water tank. Each test was conducted in a closed fermenter, the TS $\%$ for the feedstock was $10 \%$, and the percentage of inoculum in the feedstock was $20 \%$ based on weight. The headspace of digesters was flushed with nitrogen gas for about $5 \mathrm{~min}$ to obtain anaerobic condition, after which digesters were capped tightly with rubber stoppers and incubated at $30 \pm 1{ }^{\circ} \mathrm{C}$. The fermentation time was 27 days, which was determined when almost the tests had no biogas produced. Each condition was repeated three times, the standard deviation was thereby calculated as error bar.

\subsection{Analytical methods}

2.3.1. Chemical composition analyses. TS and $\mathrm{pH}$ were determined according to the Standard procedure for analyzing

Table 1 Compositions of raw material and inoculum

\begin{tabular}{lrl}
\hline Parameter & \multicolumn{1}{c}{ Rice straw } & Inoculum \\
\hline C/N & $42.48 \pm 0.13$ & $20 \pm 0.35$ \\
TS (\%) & $95 \pm 0.42$ & $10 \pm 0.12$ \\
C (\%) & $37.92 \pm 0.45$ & - \\
H (\%) & $21.32 \pm 0.32$ & - \\
L (\%) & $9.82 \pm 0.43$ & -
\end{tabular}

Table 2 Freeze-thaw pretreatment conditions

\begin{tabular}{lll}
\hline Samples & Temperature $\left({ }^{\circ} \mathrm{C}\right)$ & Time $(\mathrm{h})$ \\
\hline A1 & $-4{ }^{\circ} \mathrm{C}$ & 12 \\
A2 & & 24 \\
A3 & & 48 \\
B1 & $-20{ }^{\circ} \mathrm{C}$ & 12 \\
B2 & & 24 \\
B3 & - & 48 \\
CK & - & -
\end{tabular}

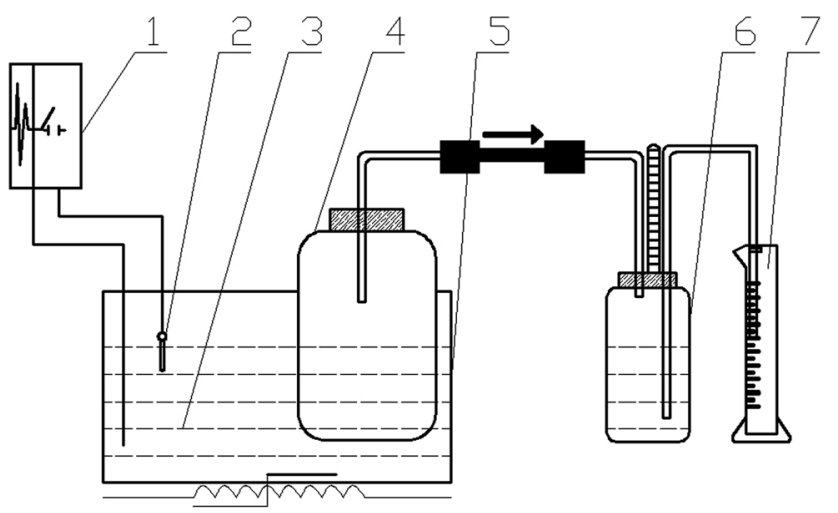

Fig. 1 Experimental installation. (1) Temperature controller, (2) temperature sensor, (3) heating wire, (4) fermentation tank $2000 \mathrm{~mL}$, (5) thermostatic water tank, (6) gas collecting tank, (7) cylinder.

water and wastewater. ${ }^{25}$ Total carbon (TOC) was measured using Shimadzu total organic carbon analyzer (TOC-L, SHIMADAZU, JPN). Total nitrogen (TN) was measured by Kay Method of nitrogen determination. ${ }^{\mathbf{2 6}}$ Van Soest crude fiber assay was used to determine cellulose, hemicellulose, and lignin contents. ${ }^{27}$

2.3.2. Biogas analyses. Biogas production was monitored every two days by using the method of water displacement, the water was saturated with sodium chloride. ${ }^{28}$ When $\mathrm{AD}$ was completed, total biogas volume was calculated. Gas chromatograph (GC) (Agilent Technologies, 7890A, Wilmington, DE, USA) equipped with a $25 \mathrm{~m} \times 530 \mu \mathrm{m} \times 20 \mu \mathrm{m}$ chromatographic column and a thermal conductivity detector (TCD) was used to analyze methane content. Hydrogen was used as a carrier gas at

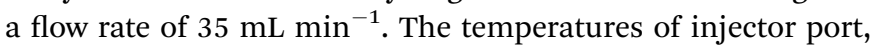
detector, and column oven were $75{ }^{\circ} \mathrm{C}, 150{ }^{\circ} \mathrm{C}$ and $40{ }^{\circ} \mathrm{C}$ respectively. $39.9 \% \mathrm{CH}_{4}, 30.1 \% \mathrm{~N}_{2}$, and $30.0 \% \mathrm{CO}_{2}$ constitute the composition of standard gas.

2.3.3. Scanning electron microscopy. After drying, samples were sputter-coated with gold, ${ }^{29}$ quanta 450FEG scanning electron microscope (FEI, USA) was then applied to take photos of the samples.

2.3.4. Statistical analysis. SPSS 19.0 software was used to determine the standard deviations and whether the observed differences between two or more groups of experimental results were significant. Differences were compared with a $p$-value of 0.05 . 

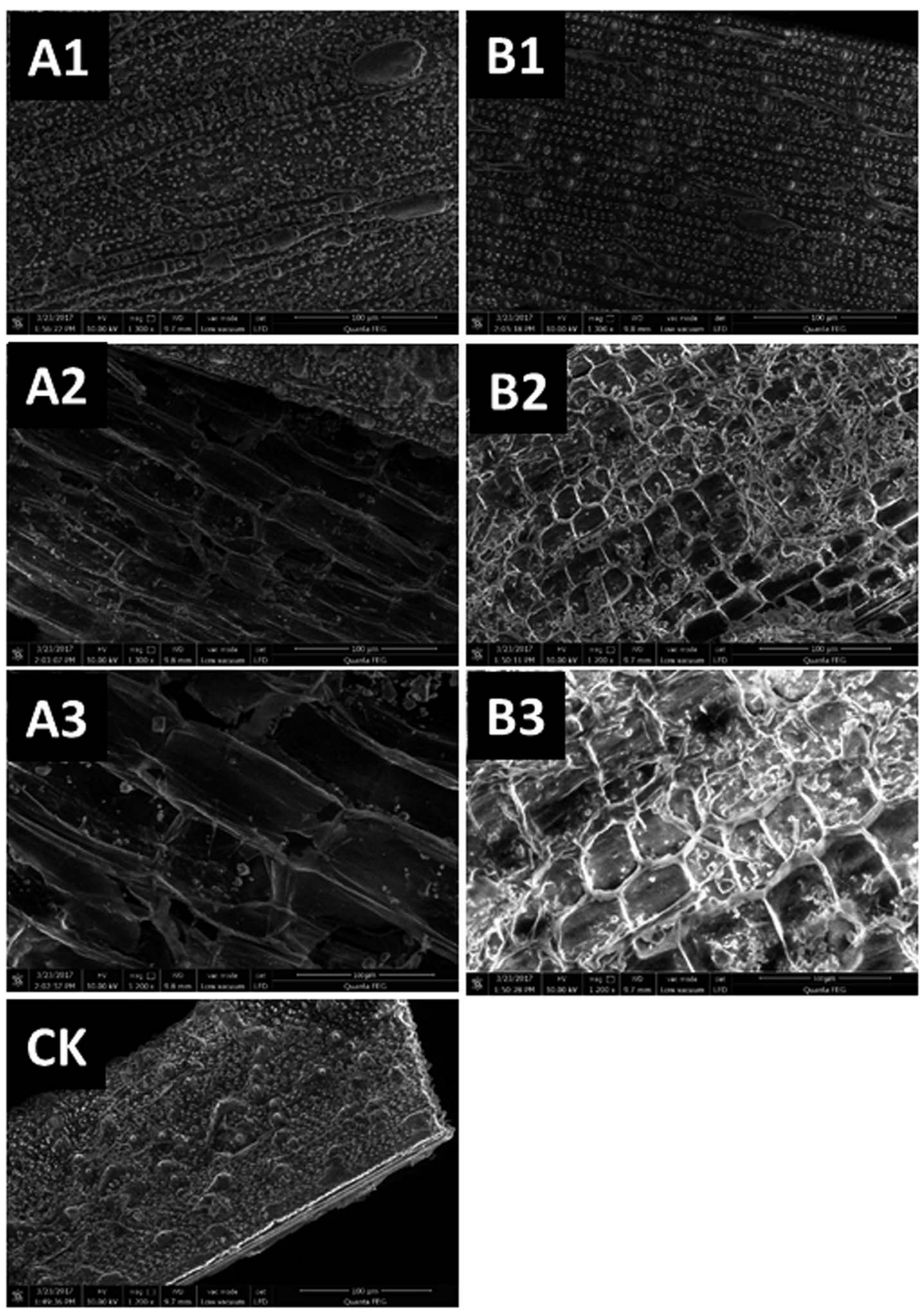

Fig. 2 Scanning electron microscope images of the pretreated rise straws and control. (1300 times). (A1): $-4{ }^{\circ} \mathrm{C}, 12 \mathrm{~h}$; (A2): $-4{ }^{\circ} \mathrm{C}, 24 \mathrm{~h} ;(\mathrm{A} 3)$ : $-4{ }^{\circ} \mathrm{C}, 48 \mathrm{~h}$; (B1): $-20{ }^{\circ} \mathrm{C}, 12 \mathrm{~h}$; (B2): $-20{ }^{\circ} \mathrm{C}, 24 \mathrm{~h}$; (B3): $-20{ }^{\circ} \mathrm{C}, 48 \mathrm{~h}$; (CK): with no treatment.

Table 3 Effect of freezing and thawing pretreatment on degradation of rice straw composition

\begin{tabular}{|c|c|c|c|c|c|c|}
\hline \multirow[b]{2}{*}{ Tests } & \multicolumn{3}{|l|}{ Contents (\%) } & \multicolumn{3}{|c|}{ Degradation (\%) } \\
\hline & $\mathrm{C}$ & $\mathrm{H}$ & $\mathrm{L}$ & $\mathrm{C}$ & $\mathrm{H}$ & $\mathrm{L}$ \\
\hline A1 & $37.24 \pm 0.57$ & $19.34 \pm 0.32$ & $9.70 \pm 0.10$ & $1.8 \pm 0.20$ & $9.3 \pm 0.31$ & $1.2 \pm 0.10$ \\
\hline $\mathrm{A} 2$ & $36.55 \pm 0.45$ & $16.42 \pm 0.28$ & $9.20 \pm 0.09$ & $3.6 \pm 0.11$ & $23.0 \pm 0.25$ & $6.3 \pm 0.05$ \\
\hline A3 & $36.44 \pm 0.47$ & $15.99 \pm 0.31$ & $8.82 \pm 0.12$ & $3.9 \pm 0.10$ & $25.0 \pm 0.30$ & $10.2 \pm 0.10$ \\
\hline B1 & $36.97 \pm 0.37$ & $18.55 \pm 0.25$ & $9.22 \pm 0.10$ & $2.5 \pm 0.10$ & $13.0 \pm 0.21$ & $6.1 \pm 0.05$ \\
\hline B2 & $36.37 \pm 0.41$ & $15.65 \pm 0.20$ & $8.73 \pm 0.11$ & $4.1 \pm 0.17$ & $26.6 \pm 0.18$ & $11.1 \pm 0.08$ \\
\hline B3 & $36.29 \pm 0.42$ & $15.48 \pm 0.25$ & $8.40 \pm 0.10$ & $4.3 \pm 0.31$ & $27.4 \pm 0.13$ & $14.5 \pm 0.07$ \\
\hline CK & $37.92 \pm 0.40$ & $21.32 \pm 0.15$ & $9.82 \pm 0.10$ & - & - & - \\
\hline
\end{tabular}




\section{Results and discussion}

\subsection{Pretreatment}

3.1.1. The microstructure changes of rice straw with pretreatment. The apparent structure of rice straw before and after pretreatment was observed using SEM. As can be seen from Fig. 2, the apparent structure of rice straw for CK group is closely regulated, and there are apparently rough particle bulges. The surface of the straw is neatly covered by siliceous projections, silicon cells, and tethered cells, and occasional cavities are visible. After freeze-thaw pretreatment, with the decrease of freezing temperature and the prolongation of freezing time, the particulate matter was significantly removed. The structure in groups A and B was destroyed to varying degrees, and the outer surface of siliceous projections, waxes, and cork has been basically removed, the apparent structure became looser, more holes appeared on the surface of solids and the size became larger, the surface area increased accordingly. The available surface area is an important factor for the accessibility of enzyme in subsequent hydrolysis. ${ }^{30}$ The increased surface area and the loose structure of solids after pretreatment allowed enzymes to penetrate more easily, absorb faster and hydrolyze lignocellulosic materials more effectively. ${ }^{\mathbf{} 1}$ Therefore, freeze-thaw pretreatment has the potential of facilitating enzyme hydrolysis and then a higher methane production can be obtained.

3.1.2. Degradations of rice straw after pretreatment. The composition of rice straw after freeze-thaw pretreatment is shown in Table 3. The $\mathrm{C}, \mathrm{H}$, and $\mathrm{L}$ contents decreased to varying degrees, and the degradations of $\mathrm{C}, \mathrm{H}$, and $\mathrm{L}$ are $1.8-4.3 \%$. 9.3-
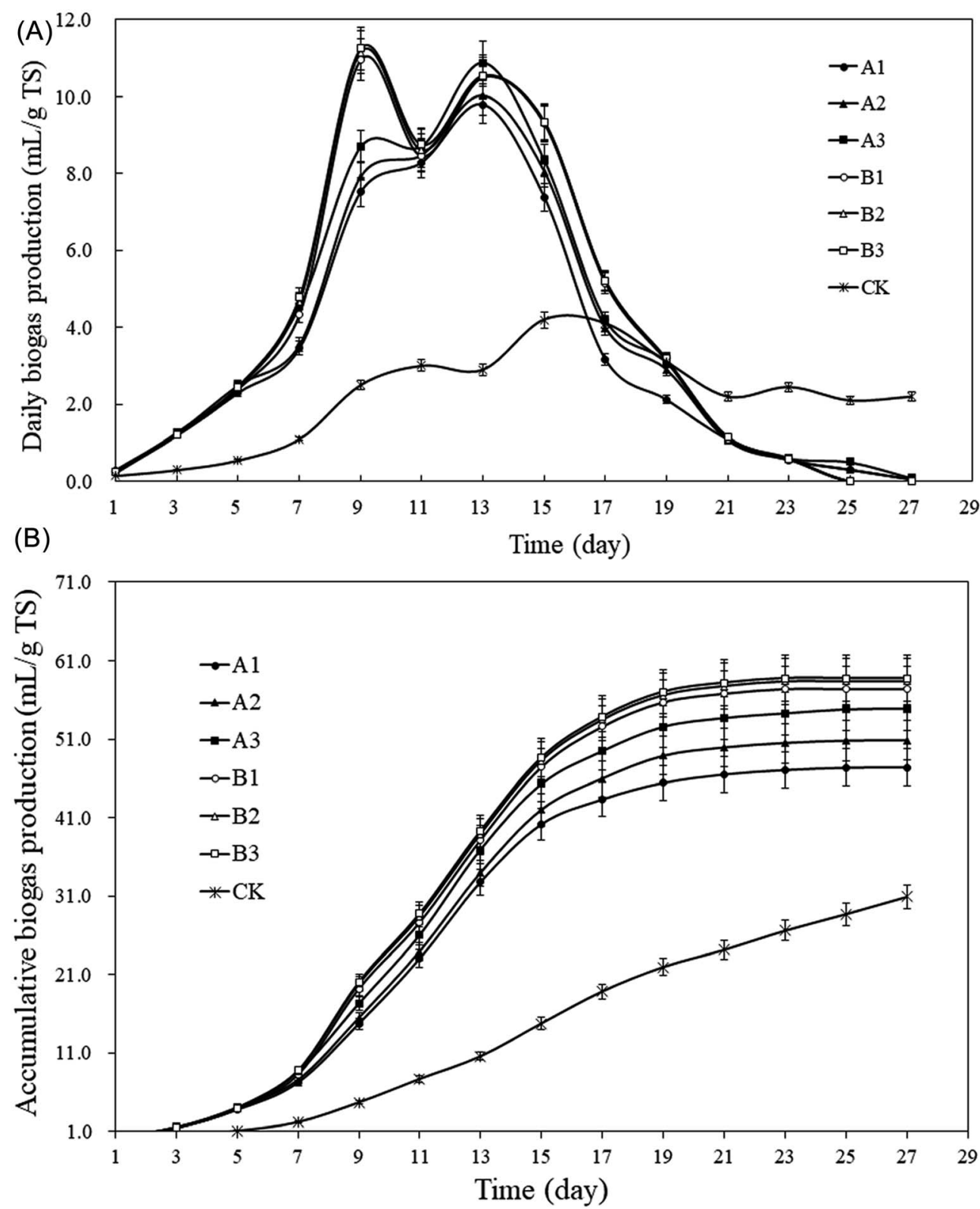

Fig. 3 Biogas production from the pretreated rise straws and control. (A): Daily biogas production; (B): accumulative biogas production. 
$27.4 \%$ and $1.2-14.5 \%$, respectively. Notably, the reduction of $\mathrm{C}$ was less than $\mathrm{H}$ and $\mathrm{L}$, this result is different from previous studies, ${ }^{29,32,33}$ meaning that more $\mathrm{C}$, as the major source for methane production, can be remained after pretreatment. During the freezing process, the swelling of water leads to the increase of water volume, which can destroy the hydrogen bonds in the straw, and then reduce the degree of polymerization, which is beneficial for the dissolution of the polymer, the dense and hard lignocellulose thereby becomes loose. The internal area of samples and the volume of holes are conducive to the attachment, growth and reproduction of microorganisms, ${ }^{34}$ this will be significant for the biomass conversion and thereby the improvement of methane production.

\subsection{Anaerobic digestion}

3.2.1. Biogas production. The effect of different freezing conditions on the daily biogas production is shown in Fig. 3A. It can be seen that there are peaks of biogas production appeared for group-A and -B. In group A, the peak of biogas production occurred on the $13^{\text {th }}$ day, the values were A1: $9.8 \mathrm{~mL} \mathrm{~g}^{-1} \mathrm{TS}, \mathrm{A} 2$ : $10.0 \mathrm{~mL} \mathrm{~g}^{-1} \mathrm{TS}$, and $\mathrm{A} 3: 10.9 \mathrm{~mL} \mathrm{~g}^{-1} \mathrm{TS}$, respectively. However, the peak in group B appeared on the $9^{\text {th }}$ day, the values of peak were B1:11.0 $\mathrm{mL} \mathrm{g}^{-1} \mathrm{TS}, \mathrm{B} 2: 11.2 \mathrm{~mL} \mathrm{~g}^{-1} \mathrm{TS}$, B3: $11.3 \mathrm{~mL} \mathrm{~g}^{-1} \mathrm{TS}$, which was 5 days earlier compared with group A, It can be observed that the lower the temperature is, the sooner the peak comes, and the higher the peak reaches. However, for control, the level of daily biogas production was the lowest among all the tests, this is due to the complex structure of raw samples which can not be easily utilized by microbes for biogas production. From Fig. 3B, the accumulative biogas productions for group A were: A1: $47.4 \mathrm{~mL} \mathrm{~g}^{-1} \mathrm{TS}$, A2: $50.9 \mathrm{~mL} \mathrm{~g}^{-1} \mathrm{TS}$, and $\mathrm{A} 3$ : $54.8 \mathrm{~mL} \mathrm{~g}^{-1} \mathrm{TS}$, respectively, and for group $\mathrm{B}$, the accumulative biogas production were: $\mathrm{B} 1: 57.4 \mathrm{~mL} \mathrm{~g}^{-1} \mathrm{TS}$, B2: $58.4 \mathrm{~mL} \mathrm{~g}^{-1} \mathrm{TS}$, and B3: $58.7 \mathrm{~mL} \mathrm{~g}^{-1} \mathrm{TS}$, respectively, which were $53.7-77.7 \%$

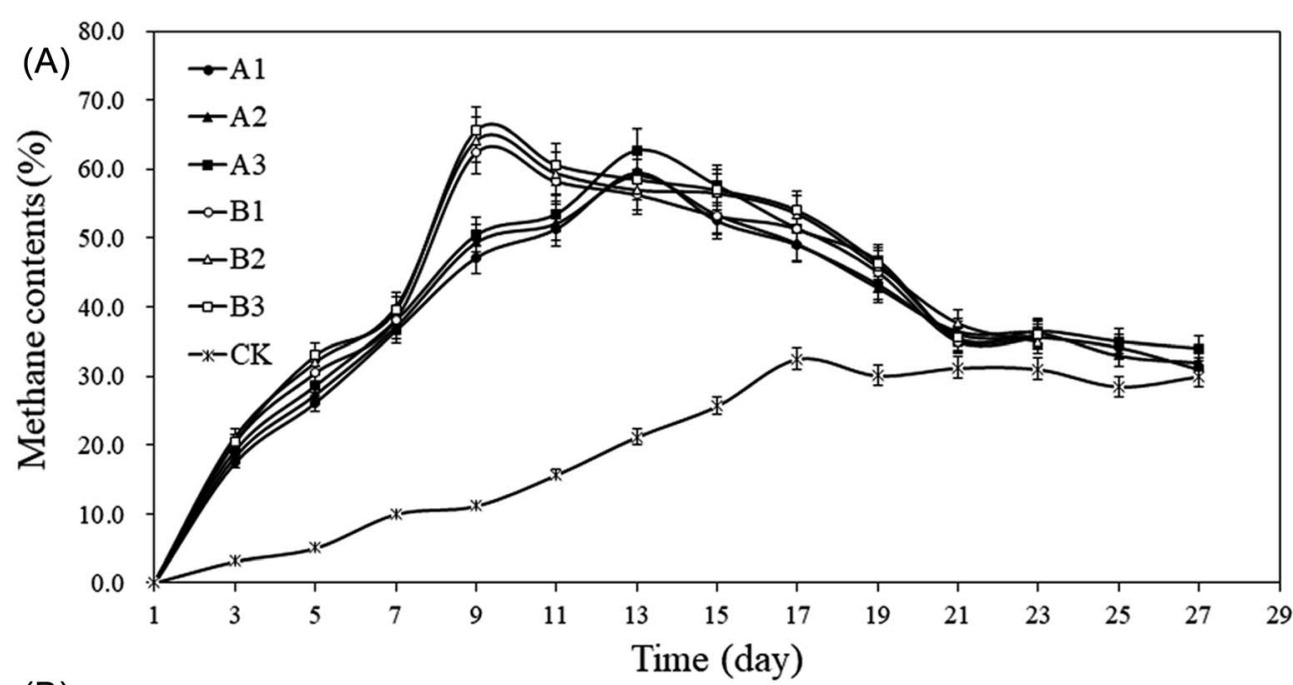

(B)

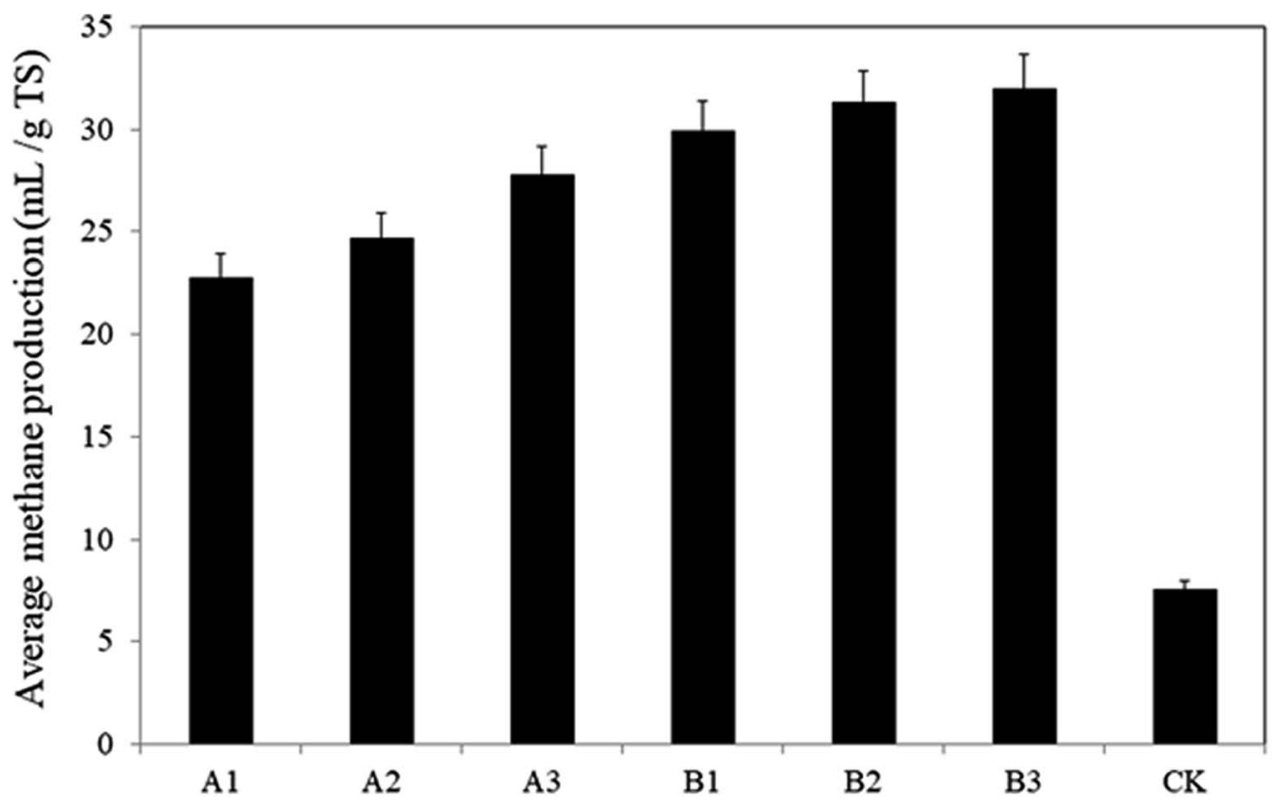

Fig. 4 Methane content from the pretreated rise straws and control. (A): Methane content; (B): average methane production. 
and $86.0-90.3 \%$ higher than control $\left(30.9 \mathrm{~mL} \mathrm{~g}^{-1} \mathrm{TS}\right)$, respectively. It can be concluded that, at the same freezing temperature, the accumulative biogas production increased with the extension of the freezing time. This is due to the existence of a large number of hydroxyl groups and hydrogen bonds in the cellulose and hemicellulose molecules of rice straw and its intermolecular structure, which is beneficial for rice straw to hold water, but the structure of lignocellulose is dense and contains crystalline area, making it difficult for water molecules to permeate. However, the water volume in the lignocellulosic structure expands after the ice formation, and the capacity of water holding increases with the extension of freezing time within a certain range, which is more conducive to the increase of gap size in samples, the increase of area for microorganisms to attach. ${ }^{35}$ On the other hand, at the same time, the accumulative biogas production increased significantly with the decrease of freezing temperature $(p<0.05)$. According to previous studies, this is due to the lower surface temperature compared with the internal part of lignocellulose during the freezing process. ${ }^{35}$ As the freezing temperature decreases, the volume of free water in the surface pores first expands, and the water molecule in the pores needs to overcome the viscous resistance while moving, the resulted pressure gradients of water have a significant destruction on the lignocellulosic structure. ${ }^{35}$ The adsorption of the water molecule occurs only in the amorphous region of the cellulose, so the bound water that forms hydrogen bonds with hydroxyl groups in the amorphous region of cellulose, the internal volume of lignocellulosic structure will increase due to the decrease of cohesion, the solids will become soft, and swelling will occur. ${ }^{36}$ Destroying the lignocellulosic structure of rice straw through the water volume expansion technology resulted by freeze is beneficial for the improvement of biogas production.

3.2.2. Methane content. Fig. 4A shows the trends of methane content and Fig. 4B shows the average methane content.

From Fig. 4A, the methane content of group A showed a trend of increasing first and then decreasing followed by a stable status. The methane contents peaked on the $13^{\text {th }}$ day, which were: A1: 59.5\%, A2: 59.1\%, A3: 62.7\%, respectively, and began to decrease whereafter, and the methane content remained over $40 \%$. According to Fig. $4 \mathrm{~B}$, the average methane contents were: A1: $40.0 \%$, A2: 40.5\%, and A3: 42.2\%, which was 88.8-99.1\% higher than CK (21.2\%). The peak in group B appeared on the $9^{\text {th }}$ day and 4 days earlier than that in group $\mathrm{A}$ (Fig. 4A), the values of peak were: B1: $62.4 \%$, B2: $64.2 \%$, B3: $65.6 \%$, respectively, the methane content remained over $35 \%$. The average methane contents were: B1: 44.2\%, B2: 45.7\%, B3: $46.0 \%$ (Fig. 4B), which were 108.6-117.2\% higher than that of CK. The average methane content for CK remained the lowest level throughout the $\mathrm{AD}$ process and the highest value was only $32.5 \%$. Straw is rich in cellulose, hemicellulose and lignin, this three components are intertwined and form a sturdy spatial structure that is not easily decomposed by microorganisms and enzymes. ${ }^{37}$ General comminution can't provide sufficient attachment sites for microorganisms, the wax coating on the solids surface even make microorganisms more difficult to decompose the straw. ${ }^{38}$ In addition, the moisture content of raw straw is only $5 \%$, which lead to floating and crusting problems during the $\mathrm{AD}$ process, making $\mathrm{CK}$ not function well.

The increasing trends of average methane content in groups $\mathrm{A}$ and $\mathrm{B}$ are in line with the growth curve of methanogens. Methanogens are the only group of microorganisms that mainly produce methane under anaerobic conditions. They convert a few low-carbon compounds into methane with obtaining energy for their growth. Methanogens cannot use complex organic matter and can only use the intermediates or final metabolites produced by other groups of microorganisms for their growth and breeding. Therefore, in the early stage of $\mathrm{AD}$, the proliferation rate is much lower than that of acid-producing bacteria. From Fig. 4A, it can be seen that the methane contents for groups A and B and CK in the first 3 days were low. At this time, acid-producing bacteria was dominant in the $\mathrm{AD}$ system. The $\mathrm{pH}$ decreased significantly along with the increase in metabolism of aerobic acid-producing bacteria (Fig. 5), which further inhibited the growth and reproduction of methanogens.

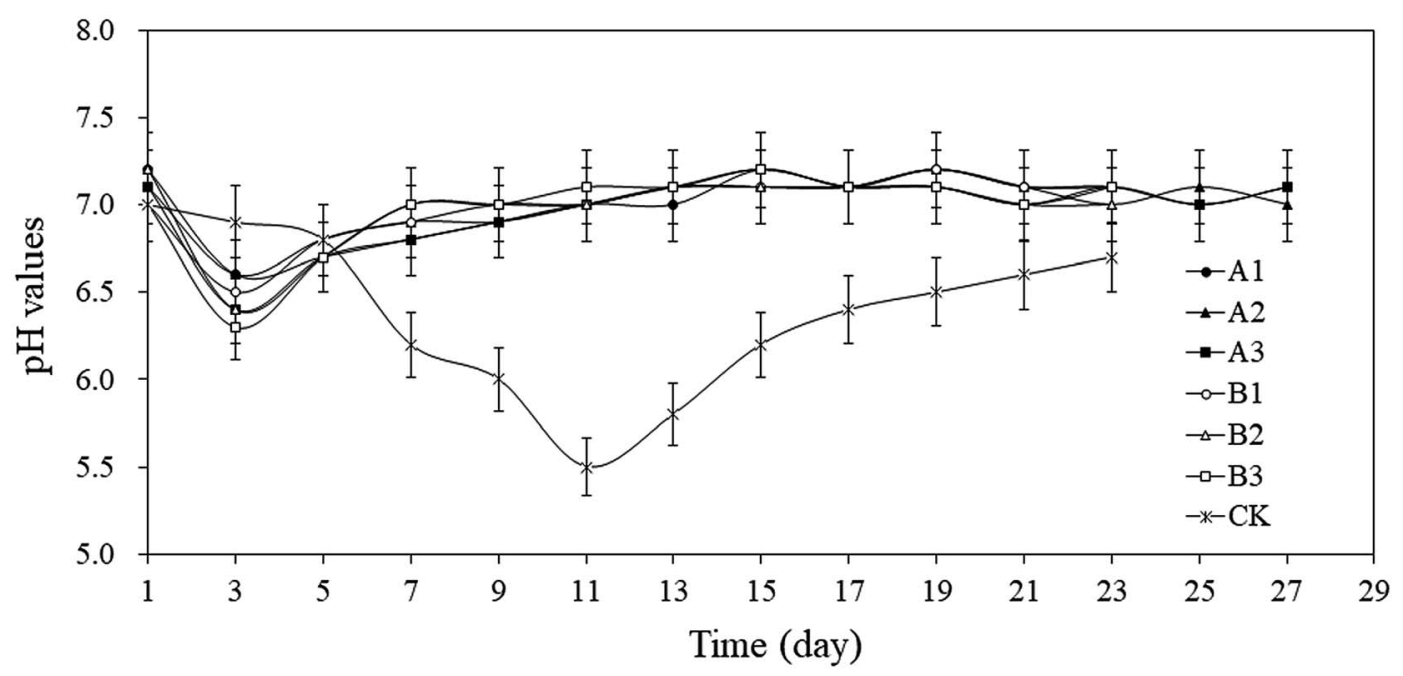

Fig. $5 \mathrm{pH}$ value variation of the pretreated rise straws and control during anaerobic digestion. 
With the consumption of oxygen in the $\mathrm{AD}$ system and the increase of reducing substances, the redox potential dropped rapidly, the number of the bacteria decreased sharply and the number of anaerobes began to increase significantly. ${ }^{39}$ At this time, the number of methanogens, anammox bacteria, and anaerobic acid-producing bacteria reached the peak value. ${ }^{40}$ The rapid proliferation of methanogens is a main reason to the rapid increase of methane content. Following the $9-13^{\text {th }}$ day, the growth of methanogens enters a stable period, meaning the balance between the increase rate of methanogens and the mortality rate occur, the methane content in the $\mathrm{AD}$ system remains in a relatively stable range. Afterwards, the methane contents began to drop due to the depletion of easily decomposable substrates.
3.2.3. $\mathrm{pH}$ changes. $\mathrm{pH}$ value for a normal $\mathrm{AD}$ system is $6-8$, and the optimum $\mathrm{pH}$ value is 7.0. ${ }^{41}$ In an $\mathrm{AD}$ system with lower $\mathrm{pH}$, biogas fermentation microorganisms need more energy to pump protons out of the cell body to maintain its cytoplasmic in the neutral $\mathrm{pH}$ range, which will cause the decline of biological metabolic rate. ${ }^{42}$ The feedstock for groups $\mathrm{A}$ and $\mathrm{B}$ prior to $\mathrm{AD}$ was neutral. After start-up of $\mathrm{AD}$, the $\mathrm{pH}$ of $\mathrm{AD}$ system quickly dropped and even fell to 6.3 (B3), because carbon-rich compounds such as rice straw are prone to acidification during $\mathrm{AD}$ process (Fig. 5). ${ }^{43}$ In addition, the grow rate of methanogenic bacteria is lower than those of fermentative and acetogenic bacteria, therefore methanogenic bacteria are sensitive to changes in the growth environment. ${ }^{44}$ Therefore, as can be seen from Fig. 5, within the first 3 days of AD, the daily
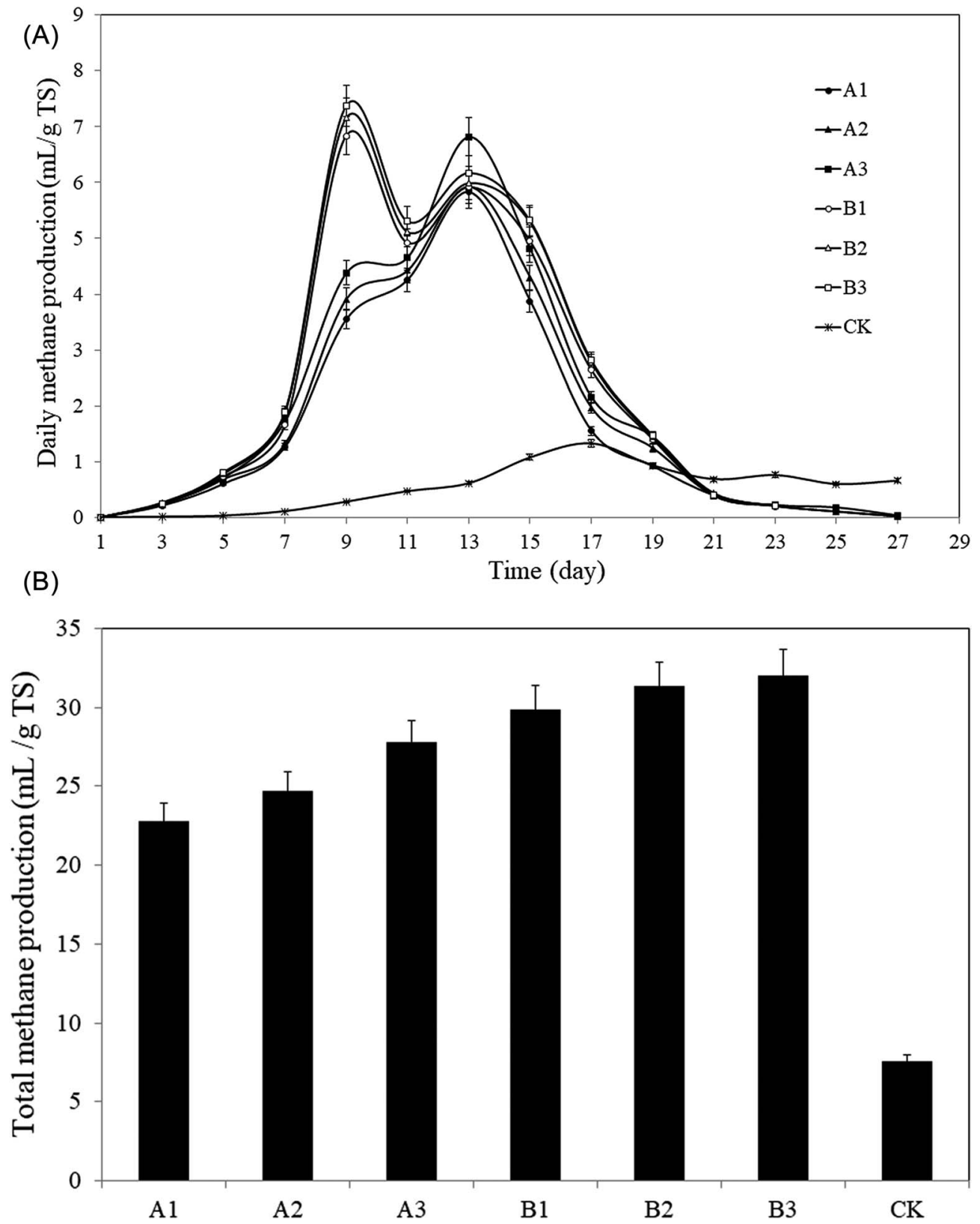

Fig. 6 Methane production from the pretreated rise straws and control. (A): Daily methane production; (B): total methane production. 
biogas production maintained at a low level $\left(\leq 1.3 \mathrm{~mL} \mathrm{~g}^{-1} \mathrm{TS}\right)$ with the decrease of $\mathrm{pH}$ value. $\mathrm{pH}$ for groups $\mathrm{A}$ and $\mathrm{B}$ began to recover steadily from the $4^{\text {th }}$ day onwards. The methanogens increased along with the proceeding of $\mathrm{AD}$ and began to increasingly use the metabolites (mainly acetic acid) produced by aerobic microbial, the $\mathrm{pH}$ of $\mathrm{AD}$ system gradually recovered accordingly and maintained in a alkaline level. ${ }^{45}$ Compared with CK, groups A and B could more quickly complete the hydrolysis and acidification stage and enter the methanogenic stage, indicating that the freeze-thaw pretreatment plays a key role in relieving excessive acidification during $\mathrm{AD}$ process.

3.2.4. Methane production. As shown in Fig. $6 \mathrm{~A}$ and $\mathrm{B}$, the trends of daily methane production and total methane production for groups A and B and CK are similar to that of daily biogas production and average methane content. In addition to the accumulative biogas production and average methane content as aforementioned, total methane production can be used for directly evaluating the efficiency of energy conversion from biomass. In this study, the total methane production for groups A and B and CK were A1: $22.8 \mathrm{~mL} \mathrm{~g}^{-1} \mathrm{TS}, \mathrm{A} 2: 24.7 \mathrm{~mL} \mathrm{~g}^{-1}$ TS, A3: $27.8 \mathrm{~mL} \mathrm{~g}^{-1} \mathrm{TS}$; B1: $29.9 \mathrm{~mL} \mathrm{~g}^{-1} \mathrm{TS}, \mathrm{B} 2: 31.3 \mathrm{~mL} \mathrm{~g}^{-1} \mathrm{TS}$, B3: $32.0 \mathrm{~mL} \mathrm{~g}^{-1} \mathrm{TS}$; $7.6 \mathrm{~mL} \mathrm{~g}^{-1} \mathrm{TS}$, respectively (Fig. 6B). Compared with CK, the increases of groups A and B were 200.0$265.8 \%$, 293.4-321.1\%, respectively. The maximum of total methane production was obtained at conditions of $-20{ }^{\circ} \mathrm{C}$ and 48 h. Therefore, the pretreatment proposed in this study significantly enhanced the biomass conversion with up to $321.1 \%$ increase of methane production, which is beneficial for improving the applicability of $\mathrm{AD}$ technique.

The technical digestion time $\left(T_{80}\right)$ can be used to indicate the biodegradability of the substrate. ${ }^{46,47} T_{80}$ is the time required to reach $80 \%$ of total gas production. ${ }^{\mathbf{4 8 , 4 9}}$ The $\mathrm{AD}$ in this study lasted for 27 days. $T_{80}$ values for groups A and B and CK were A1: 15 days, A2: 15 days, A3: 15 days; B1: 15 days, B2: 15 days, B3: 15 days; 23 days, respectively. Therefore, $T_{80}$ for groups $\mathrm{A}$ and $\mathrm{B}$ after pretreatment was shortened by 8 days $(p<0.05)$, which means the proceeding of AD was significantly accelerated by the pretreatment, and a certain amount of biomass can be anaerobically converted to bioenergy with shorter time.

As a result, the pretreatment helped significantly improving the methane production and accelerating the proceeding of $\mathrm{AD}$.

\section{Conclusion}

The low temperature freeze-thaw pretreatment proposed herein enhanced the $\mathrm{AD}$ efficiency: the total methane productions at $-4{ }^{\circ} \mathrm{C}$ and $-20{ }^{\circ} \mathrm{C}$ were $200.0-265.8 \%, 293.4-321.1 \%$ higher, respectively, compared with $\mathrm{CK}\left(7.6 \mathrm{~mL} \mathrm{~g}^{-1} \mathrm{TS}\right)$. Compared with CK $(21.2 \%)$, the average methane contents for groups A and B were $88.8-99.1 \%$ and $108.6 \%-117.2 \%$ higher, respectively. The lower the pretreatment temperature was, the sooner the peak of biogas production came, the higher the peak value reached. $\mathrm{pH}$ of $\mathrm{AD}$ system rebounded more quickly, which played a key role in relieving the over-acidification that usually occur during $\mathrm{AD}$ process.

\section{Conflicts of interest}

There are no conflicts to declare.

\section{Acknowledgements}

This study was funded by the Program of the National Natural Science Foundation of China (51576167).

\section{References}

1 M. J. Taherzadeh and K. Karimi, Int. J. Mol. Sci., 2008, 9, 1621-1651.

2 K. Bernat, M. Zielińska, A. Cydzik-Kwiatkowska and I. Wojnowska-Baryła, Biochem. Eng. J., 2015, 100, 30-40.

3 Z. Sapci, Bioresour. Technol., 2013, 128, 487-494.

4 C. Sun, R. Liu and G. Qin, Trans. Chin. Soc. Agric. Mach., 2010, 41, 94-120.

5 J. Zhu, C. Wan and Y. Li, Bioresour. Technol., 2010, 101, 75237528.

6 J. Lalak, A. Kasprzycka, D. Martyniak and J. Tys, Bioresour. Technol., 2016, 200, 194-200.

7 K. Michalska, M. Bizukojć and S. Ledakowicz, Biomass Bioenergy, 2015, 80, 213-221.

8 W. Zhong, Z. Zhang, Y. Luo, S. Sun, W. Qiao and M. Xiao, Bioresour. Technol., 2011, 102, 11177-11182.

9 G. Di Girolamo, M. Grigatti, L. Bertin, C. Ciavatta and L. Barbanti, Biomass Bioenergy, 2016, 85, 306-312.

10 F. Monlau, C. Sambusiti, A. Barakat, M. Quéméneur, E. Trably, J.-P. Steyer and H. Carrère, Biotechnol. Adv., 2014, 32, 934-951.

11 M. Quéméneur, J. Hamelin, A. Barakat, J.-P. Steyer, H. Carrère and E. Trably, Int. J. Hydrogen Energy, 2012, 37, 3150-3159.

12 P. M. Christy, L. Gopinath and D. Divya, Renewable Sustainable Energy Rev., 2014, 34, 167-173.

13 S. Van Kuijk, A. Sonnenberg, J. Baars, W. Hendriks and J. Cone, Biotechnol. Adv., 2015, 33, 191-202.

14 X. Li, J. Zhao, D. Wang, Q. Yang, Q. Xu, Y. Deng, W. Yang and G. Zeng, Chemosphere, 2016, 144, 160-167.

15 M. Mora-Pale, L. Meli, T. V. Doherty, R. J. Linhardt and J. S. Dordick, Biotechnol. Bioeng., 2011, 108, 1229-1245.

16 J. Müller, Water Sci. Technol., 2001, 44, 121-128.

17 A. Montusiewicz, M. Lebiocka, A. Rożej, E. Zacharska and L. Pawłowski, Bioresour. Technol., 2010, 101, 3466-3473.

18 Z. He, A. Zhou, C. Yang, Z. Guo, A. Wang, W. Liu and J. Nan, RSC Adv., 2015, 5, 48413-48420.

19 C. Phalakornkule, S. Nuchdang, M. Khemkhao, W. Mhuantong, S. Wongwilaiwalin, S. Tangphatsornruang, V. Champreda, J. Kitsuwan and S. Vatanyoopaisarn, J. Biosci. Bioeng., 2017, 123, 474-481.

20 T. Meyer, X. Chen, H. N. Tran, D. G. Allen and E. A. Edwards, Environ. Eng. Sci., 2017, 34, 357-366.

21 J. Diak and B. Örmeci, J. Environ. Manage., 2017, 216, 406420.

22 P. Keymer, I. Ruffell, S. Pratt and P. Lant, Bioresour. Technol., 2013, 131, 128-133. 
23 K.-L. Chang, J. Thitikorn-amorn, J.-F. Hsieh, B.-M. Ou, S.-H. Chen, K. Ratanakhanokchai, P.-J. Huang and S.-T. Chen, Biomass Bioenergy, 2011, 35, 90-95.

24 J. Pan, L. Qiu, A. Hassanein, T. Gao and Y. Liang, Trans. Chin. Soc. Agric. Mach., 2014, 45, 229-233.

25 W. E. Federation American Public Health Association, American Public Health Association (APHA), Washington, DC, USA, 2005.

26 W. Dickinson, Anal. Chem., 1958, 30, 992-994.

27 P. J. Van Soest and R. H. Wine, J. Assoc. Off. Anal Chem., 1967, 50, 50-55.

28 E. S. Hernández and L. T. Córdoba, Resour., Conserv. Recycl., 1993, 9, 127-132.

29 Y. Yao, M. He, Y. Ren, L. Ma, Y. Luo, H. Sheng, Y. Xiang, H. Zhang, Q. Li and L. An, Bioresour. Technol., 2013, 134, 347-352.

30 A. Hendriks and G. Zeeman, Bioresour. Technol., 2009, 100, 10-18.

31 Y. H. P. Zhang and L. R. Lynd, Biotechnol. Bioeng., 2004, 88, 797-824.

32 Y. Yao, S. Chen and G. K. Kafle, J. Environ. Manage., 2017, 193, 423-429.

33 Y. Yao, J. Zhou, L. An, G. K. Kafle, S. Chen and L. Qiu, Energy, 2018, 151, 998-1006.

$34 \mathrm{~J}$. Li, Y. Lu, D. Yang, Q. Sun, Y. Liu and H. Zhao, Biomacromolecules, 2011, 12, 1860-1867.

35 K.-L. Chang, J. Thitikorn-amorn, J.-F. Hsieh, B.-M. Ou, S.-H. Chen, K. Ratanakhanokchai, P.-J. Huang and S.-T. Chen, Biomass Bioenergy, 2011, 35, 90-95.
36 M. Yu, L. J. Wang and X. M. Wang, Adv. Mater. Res., 2012, 550, 472-475.

37 R. Chandra, H. Takeuchi and T. Hasegawa, Renewable Sustainable Energy Rev., 2012, 16, 1462-1476.

38 Q. Yang, M. Ju and W. Li, Trans. Chin. Soc. Agric. Eng., 2016, 32, 232-242.

39 C. Vongvichiankul, J. Deebao and W. Khongnakorn, Energy Procedia, 2017, 138, 877-882.

40 G. Feijoo, M. Soto, R. Méndez and J. M. Lema, Enzyme Microb. Technol., 1995, 17, 180-188.

41 S. Riggio, M. Torrijos, R. Debord, G. Esposito, E. D. Van Hullebusch, J. P. Steyer and R. Escudié, Waste Manag., 2017, 59, 129-139.

42 U. K. Laemmli, Nature, 1970, 227, 680.

43 S. Riggio, M. Torrijos, R. Debord, G. Esposito, E. D. van Hullebusch, J. P. Steyer and R. Escudie, Waste Manag., 2017, 59, 129-139.

44 W.-j. Gong, H. Liang, W.-z. Li and Z.-z. Wang, Energy, 2011, 36, 3572-3578.

45 A. J. Ward, P. J. Hobbs, P. J. Holliman and D. L. Jones, Bioresour. Technol., 2008, 99, 7928-7940.

46 Y. Pang, Y. Liu, X. Li, K. Wang and H. Yuan, Energy Fuels, 2008, 22, 2761-2766.

47 M. Zheng, X. Li, L. Li, X. Yang and Y. He, Bioresour. Technol., 2009, 100, 5140-5145.

48 L. Palmowski and J. Müller, Water Sci. Technol., 2000, 41, 155-162.

49 G. K. Kafle, S. H. Kim and K. I. Sung, Bioresour. Technol., 2013, 127, 326-336. 